\title{
A record of anopthalmia in Mystus tengara (Hamilton, 1822) from Assam
}

\author{
Jyotish Barman*, A. K. Jaiswar, S. K. Chakraborty, Shrinivas Jahgeerdar and W. S. Lakra \\ Central Institute of Fisheries Education (Deemed University), Indian Council of Agricultural Research, Panchmarg, \\ Off Yari road, Versova, Mumbai - 400061, INDIA \\ *Corresponding author. E-mail: jyotish5@gmail.com
}

Received: June 08, 2014; Revised received: September 02, 2014; Accepted: November 01, 2014

\begin{abstract}
An abnormal case of anopthalmia in a striped catfish Mystus tengara (66.8 $\mathrm{mm}$ in standard length) from Assam is reported in this communication. Thirty eight morphological characters of the abnormal specimen were also studied and compared with normal specimens to observe variation in the morpho-meristic traits, if any. In the abnormal specimen, the proportionate height of the dorsal fin $(31.1 \mathrm{~mm})$ and nasal barbel length $(75.9 \mathrm{~mm})$ was found to be higher compared to that of the normal specimens $(21.6-26.5 \mathrm{~mm}$ and $47.9-72.5 \mathrm{~mm}$, respectively). While the body depth of anus was higher in case of normal specimens $(19.1-29.2 \mathrm{~mm})$ compared to abnormal specimen $(14.5 \mathrm{~mm})$. However, no marked variation was observed in meristic characters. This anomaly does not seem to have affected morphological aspects. Factors like weed infestation, pesticide and herbicide application adversely affecting the habitat is believed to be the cause of such deformity. The abnormality does not seem to have affected the overall growth of the fish.
\end{abstract}

Keywords: Anopthalmia, Environmental stress, Morphological anomalies, Mystus tengara

\section{INTRODUCTION}

Abnormal phenotypes, while rare, can be observed in many populations of fish (Tave and Handwerker, 1998). Morphological anomalies in fishes can be attributed to various factors like nutritional deficiency (Cahu et al., 2003), temperature variations (Gluth and Hanke, 1983), low dissolved oxygen (Turner and Farley, 1971; Anon, 1996), high carbon dioxide concentration in water (Martens et al., 2006), pollutants like chlorinated hydrocarbons, organophosphates, pesticides, heavy metals (Weis and Weis, 1989; Lin Sun et al., 2009), parasitic infection (Cunningham et al., 2005), developmental error and injury (Devadoss, 1983; Dutta and Kumar, 1991; Gupta et al., 2000 and Subba, 2008).

Anopthalmia (the congenital absence of one or both eyes) in fish have been reported by many authors. A compiled bibliography of 1499 papers on fish anomalies was given by Dawson $(1964,1966,1971)$ and Dawson and Heal (1976), of which 63 papers described eye abnormalities (Tave and Handwerker, 1998). Since then, many reports have been published on morphological anomalies in fishes (Kruitwagen et al., 2006; Tave et al., 2011; Saha and Saha, 2013).

Species of the genus Mystus are small to medium sized catfishes, inhabiting streams, lakes, and rivers of southern and southeastern Asia. Jayaram and Sanyal (2003) and Ferraris (2007) listed 44 and 33 species of Mystus, respectively. Among them, Mystus tengara
(Hamilton, 1822) is known to have a fairly wide distribution in the Ganges and Brahmaputra river basins in northern and northeastern India. The species does not face any major threats and is therefore assessed as least concern $(\mathrm{Ng}, 2010)$.

Reports on abnormality of catfish are scanty and those available are mostly related to skeletal deformity (Sarkar and Kapoor, 1956; BabuRao and Siva Reddy, 1984; Jesu et al., 2004; Teji and John Thomas, 2006; Nagarajan, 2012). However, an unusual specimen of $M$. tengara was collected from a rivulet of Brahmaputra River, Assam. The present communication is an attempt to report the case of anophthalmia in M. tengara.

\section{MATERIALS AND METHODS}

The deformed specimen of $M$. tengara (lacking right eye) was collected on $5^{\text {th }}$ December, 2013 from a rivulet of Brahmaputra river near Folimari village Part - I in the vicinity of Dhubri town (District: Dhubri), Assam, India, during routine collection of samples for taxonomic evaluation of the genus Mystus. The specimen measuring $66.8 \mathrm{~mm}$ in standard length is preserved in the museum at CIFE, Mumbai, India (CIFE/FRM/MUS/Mt-48).

Sixteen normal specimens of the same species were also collected from the same site on the same day for observation of morphological features (Fig 1). Thirty eight morphological characters (30 morphometric and 8 meristic) were recorded for comparison. For the normal specimen the data are given in range. Gillrakers 
count on the first left branchial arch was taken only for the normal specimen. Methods for counting gillrakers follow Roberts (1992). Measurements were made point to point with a digital dial Vernier caliper to the nearest $0.1 \mathrm{~mm}$. Subunits of the head are presented as proportions of head length (HL). Head length and measurements of body parts are given as proportions of standard length (SL). The inter-orbital distance of the abnormal specimen could not be measured for obvious reason and the gillraker count was also not taken to avoid damage to the specimen. Counts and measurements were taken by following $\mathrm{Ng}$ and Dodson (1999). Identification of the species was done following the key described by Jayaram (2006) and Darshan et al. (2013).

\section{RESULTS AND DISCUSSION}

The biometric features of the abnormal specimen as well as the normal specimens are presented in table 1.The dorsal fin of abnormal specimen has 7 branched rays and a spine with 3 serrations at the anterior side near the distal tip and 9 serrations at the posterior end. Pectoral fin has 7 branched rays with a stout spine having 14 large posterior serrations. Anal fin posses 3 unbranched and 9 branched rays. Caudal fin is deeply forked, and both upper and lower lobes have 1 unbranched and 7 branched rays.

The dorsal spine of normal specimens have 2-3 anterior serrations and 7-9 posterior serrations, while dorsal fin has 7 branched rays. Pectoral fin is with 7 or 8 branched rays while spine has $10-17$ posterior serrations. Pelvic fin is with 1 unbranched and 5 branched rays. The unbranched and branched rays of anal fin ranged between 2-3 and 7-9, respectively. While both lobes of the caudal fin bear 1 unbranched ray, and 6/7 and 7/8 branched rays in the upper and lower lobes, respectively. Gillraker count for the normal specimens ranged between $31-40$, with $6-9$ in the upper limb and 22 -32 in the lower limb.

In the abnormal specimen, the side of the missing eye does not show any sign of injury or damage. On the contrary, the place was slightly depressed and covered with scales (Fig 2). The reason for this abnormality could not be ascertained. However, Tave and Handwerker (1998) reported that anophthalmia either can be heritable or can be caused by environmental disturbances. Tave et al. (2011) reported gross abnormalities in tilapia pertaining to eye which were non-heritable and possibly produced by pathogen, heat shock or chemicals. Symptom of anopthalmia was also observed in carps when dissolved oxygen concentration decreases to $25 \%$ of the saturation level (Anon, 1996).Weis and Weis (1976) observed occurrence of unilateral and bilateral anopthalmia in fish embryos exposed to insecticides. Similarly, effect of pollutant causing anophthalmia in mudskipper has also been reported by Kruitwagen et al. (2006). Although it is difficult to ascertain the factor responsible for this abnormality, environmental stress could be the probable reason, since, the fish collection site is adjacent to paddy fields and there is every possible chance of pesticides or herbicide being leached into the water body, as reported by Weis and Weis (1976). Moreover, since the collection site was heavily infested with aquatic weed; extreme fluctuation in dissolved oxygen and carbon dioxide content is possible. This may be another factor responsible for occurrence of such abnormality which is well supported by the findings of Anon (1996) and Martens et al. (2006).

Fowler (1970) and Barlow (1961) reviewed that lower count of some meristic characters in fishes may be due to environmental differences. But, no such meristic variation was observed in this abnormal specimen. All counts of the abnormal specimen were within the range as in the normal specimens. However, some variation was observed in the morphometric features of the abnormal fish such as dorsal fin height, nasal barbel length and body depth at anus. The proportionate height of the dorsal fin of the abnormal specimen was higher $(31.1 \mathrm{~mm})$ as compared to that of the healthy specimens $(21.6-26.5 \mathrm{~mm})$. Similarly, nasal barbel length was also found to be higher in the abnormal



Fig. 1. Comparison of abnormal specimen (A) with normal specimen $(B)$.

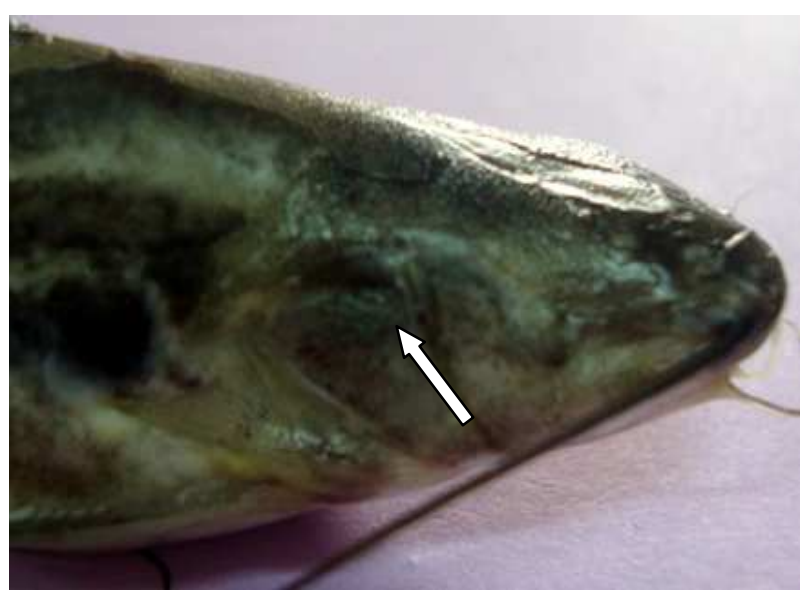

Fig. 2. Eye site of abnormal specimen covered with scale. 
Table 1. Biometric data of Mystus tengara (in mm).

\begin{tabular}{|c|c|c|c|}
\hline & \multirow[t]{2}{*}{ Abnormal specimen } & \multicolumn{2}{|c|}{ Normal specimen $(n=16)$} \\
\hline & & Range & Mean \pm SD \\
\hline Standard length (SL) & 66.8 & $55.8-82.4$ & $66.8 \pm 8.0$ \\
\hline \multicolumn{4}{|l|}{ In \% of SL } \\
\hline Pre dorsal length & 42.5 & $36.4-42.7$ & $40.6 \pm 1.3$ \\
\hline Pre pelvic length & 52.4 & $49.9-56.4$ & $52.3 \pm 2.0$ \\
\hline Pre anal length & 73.0 & $70.8-76.2$ & $73.3 \pm 1.4$ \\
\hline Pre pectoral length & 24.9 & $22.8-27.3$ & $24.8 \pm 1.3$ \\
\hline Height of dorsal fin & 31.1 & $21.6-26.5$ & $24.4 \pm 1.7$ \\
\hline Length dorsal fin base & 14.8 & $13.4-17.2$ & $15.3 \pm 1.1$ \\
\hline Dorsal spine length & 15.4 & $12.2-16.8$ & $14.9 \pm 1.5$ \\
\hline Anal fin length & 12.2 & $11.9-14.2$ & $13.1 \pm 0.8$ \\
\hline Anal fin height & 21.6 & $17.5-27.4$ & $20.2 \pm 2.4$ \\
\hline Pelvic fin length & 18.8 & $16.4-19.5$ & $17.4 \pm 0.9$ \\
\hline Pectoral fin length & 22.9 & $19.7-23.3$ & $21.2 \pm 1.0$ \\
\hline Pectoral spine length & 21.6 & $17.5-21.7$ & $19.3 \pm 1.3$ \\
\hline Caudal fin length & 28.2 & $22.5-34.9$ & $26.2 \pm 3.0$ \\
\hline Caudal peduncle length & 16.8 & $15.1-19.5$ & $16.9 \pm 1.2$ \\
\hline Caudal peduncle depth & 10.1 & $9.6-12.0$ & $10.4 \pm 0.6$ \\
\hline Adipose maximum height & 5.7 & $4.3-6.2$ & $5.0 \pm 0.6$ \\
\hline length of adipose fin base & 28.4 & $26.3-31.9$ & $29.1 \pm 1.4$ \\
\hline Post adipose distance & 13.7 & $13.4-16.5$ & $14.6 \pm 0.9$ \\
\hline Dorsal to adipose distance & 3.9 & $3.1-7.8$ & $4.7 \pm 1.3$ \\
\hline Body depth at anus & 14.5 & $19.1-29.2$ & $21.8 \pm 2.4$ \\
\hline Head Length (HL) & 29.8 & $25.6-32.0$ & $28.8 \pm 1.5$ \\
\hline Head Depth & 19.0 & $16.2-20.4$ & $18.6 \pm 1.1$ \\
\hline Head width & 19.0 & $12.3-20.3$ & $18.1 \pm 1.9$ \\
\hline \multicolumn{4}{|l|}{ In \% of $\mathrm{HL}$} \\
\hline Snout length & 28.3 & $24.3-31.3$ & $27.3 \pm 2.0$ \\
\hline Eye diameter & 27.7 & $24.1-32.6$ & $27.1 \pm 2.6$ \\
\hline Maxillary barbel length & 302.6 & $218.7-339.7$ & $289.3 \pm 30.4$ \\
\hline Nasal barbel length & 75.9 & $47.9-72.5$ & $62.7 \pm 8.2$ \\
\hline Outer mandibular barbel length & 126.9 & $109.4-152.2$ & $126.4 \pm 9.8$ \\
\hline Inner mandibular barbel length & 84.3 & $70.1-95.2$ & $80.2 \pm 6.4$ \\
\hline
\end{tabular}

specimen $(75.9 \mathrm{~mm})$ compared to that of the normal specimens $(47.9-72.5 \mathrm{~mm})$. While the body depth of anus was higher in case of normal specimens (19.1 $29.2 \mathrm{~mm}$ ) compared to abnormal specimen (14.5 mm). Records on variation in length of barbel are not available. Babu Rao and Siva Reddy (1984) observed some abnormalities in Mystus vittatus, which was mostly related to appearance of forked maxillary barbels. Bussing (1966) observed high degree of intra-specific variation in the barbel length among the population of Pygidium striatum from Costa Rica. He, however, did not report any valid reason for such variation. Subba (1999) observed deviation of length of dorsal fin height in proportion to standard length in case of African catfish pointing pollution as the reason for abnormalities. Naserizadeh et al. (2013), in their observation on morphological differences between healthy and abnormal fishes of Mahisefed (Rutilus frissikutum) populations from Caspian sea, found that abnormal fishes had different body component ratios 
for which they proposed diverse abiotic (diverse pollutants) and biotic (inbreeding) parameters as affecting factors. Deviation of body component ratio in an abnormal species of Bagarius bagarius due to developmental error was also reported by Subba (2008).

Generally the number of malformed fish, that survive, decreases with development and few individuals with abnormalities survive until adult stages (Klumpp and Von Westernhagen 1995). Similarly, Nakayama et al. (2005) reported that only few medaka embryos that developed anophthalmia following maternal exposure to tributyltin hatched successfully, and none survived for more than a few days. Hence, it is possible that the single anophthalmic $M$. tengara found in the present investigation may have malformed during development.

\section{Conclusion}

The abnormality in the fish has not induced any significant change in the gross morphological characters of the fish, while the meristic traits remain the same when compared to that of normal specimens. The absence of eye does not seem to have affected the overall growth of the fish. The possible causes of variation in length of dorsal fin, nasal barbel length and body depth at anus could be validated by conducting further investigation of more population of the species from the locality as well as analysing the soil and water quality of the collection site and adjacent areas. This shall help in undertaking suitable management measures to restore a healthy environment simultaneously conserving the fish germplasm in the long run.

\section{ACKNOWLEDGEMENT}

First author is grateful to The Director, NRC on Pig ICAR for granting study leave and to the Programme Coordinator, KVK Goalpara (ICAR) for providing necessary suggestion as and when needed. Facilities provided by the Director, CIFE (ICAR) for undertaking the research work is duly acknowledged. The authors are also thankful to the staff of FRM division, CIFE, Mumbai and the staff of Department of Fisheries, Dhubri district, Govt. of Assam for providing necessary help and support during the course of investigation.

\section{REFERENCES}

Anon (1996). Department of Water Affairs and Forestry, South African Water Quality Guidelines (2 ${ }^{\text {nd }}$ edition). Volume 6: Agricultural Waste Use: Aquaculture, pp 170.

Babu Rao, M. and Siva Reddy, Y. (1984). On an abnormal catfish Mystus vittatus Bloch, 1794 Pisces: Bagridae with a forked maxillary barbel. Bull. Zool. Surv. India, 61(3): $295-296$.

Barlow, G.W. (1961). Causes and significance of morphological variation in fishes. Syst. Zool., 10: 105-117.
Bussing, William A. (1966).New species and new records of Costa Rican freshwater fishes with a tentative list of species.Rev. Biol. Trop., 14 (2): 205 - 249.

Cahu, C., Infante, J.Z. and Takeuchi, T. (2003). Nutritional components affecting skeletal development in fish larvae. Aquaculture, 227: 245 - 258. doi:10.1016/S0044 -8486(03)00507-6.

Cunningham, M.E., Markle, D.F., Watral, V.G., Kent, M.L. and Curtis, L.R. (2005).Patterns of fish deformities and their associates with trematode cysts in the Williamette River.Oregon. Env. Biol. Fishes, 73: 9 - 19.

Darshan, A., Mahanta, P.C., Barat, A. and Kumar, P. (2013).Redescription of the striped catfish Mystus tengara (Hamilton, 1822) (Siluriformes: Bagridae), India. Journal of Threatened Taxa, 5 (1): $3536-3541$.

Dawson, C.E. (1964). A bibliography of anomalies of fishes. Gulf Res. Rep. 1, 308 - 399.

Dawson, C.E. (1966). A bibliography of anomalies of fishes, supplement 1.Gulf Res. Rep. 2, $169-176$.

Dawson, C.E. (1971). A bibliography of anomalies of fishes, supplement 2.Gulf Res. Rep. 3, 215 - 239.

Dawson, C.E. and Heal, E. (1976). A bibliography of anomalies of fishes, supplement 3.Gulf Res. Rep., 5: $35-41$.

Devadoss, P. (1983). Report on ambicolouration in Flounders. J. Fish Biol., 47(10): 168 - 170. DOI: 10.4194/13032712-v13_2_22

Dutta, S.P.S. and Kumar, S. (1991). Deformity in dorsal fin in Puntius conchonius (Ham.) from Jammu. Geobios, New Reports, 5: 173 - 174.

Ferraris, C.J. Jr. (2007). Checklist of catfishes, recent and fossil (Osteichthys: Siluriformes), and catalogue of siluriform primary types. Zootaxa, 1418: $1-628$.

Fowler, J.A. (1970). Control of vertebral number in teleosts an embryological problem.Q, Rev. Biol., 45: 148 - 167.

Gluth, G. and Hanke, W. (1983).The effect of temperature on physiological changes in carp, Cyprinus carpio L. induced by phenol. Ecotoxicol. Environ. Saf., 7(4): 373 389.

Gupta, S.C., Dutta, S.P.S. and Sharma, N. (2000). A report on some morphological deformities in silver carp Hypophthalmicthy smolitrix (Valenciennes) inhabiting aquatic environment of Jammu (J\&K). Himalayan $J$. Env. And Zool., 14: 25 - 30.

Jayaram, K.C. and Sanyal, A. (2003). A taxonomic revision of the fishes of the genus Mystus Scopoli (Family: Bagridae). Rec. Zool. Surv. India, Miscellaneous Publication, Occasional Paper no. 207: 1-136.

Jayaram, K.C. (2006). Catfishes of India. Narendra Publishing House, Delhi, 383 pp.

Jesu Arockia Raj, A., Seetharaman, S. and Haniffa, M.A. (2004). Skeletal deformities in a few freshwater fishes from Bhavaniriver, Tamil Nadu. Zoo's Print Journal, 19 (9): 1628 - 1629.

Klumpp, D.W. and Von Westernhagen, H. (1995). Biological effects of pollutants in Australian tropical coastal waters: embryonic malformations and chromosomal aberrations in developing fish eggs. Marine Pollut. Bull., 30: 158 - 165.

Kruitwagen, G., Hecht, H., Pratap, H.B. and WendelaarBonga, S.E. (2006). Changes in morphology and growth of the mudskipper (Periophthalmus argentilineatus) associated with coastal pollution. Mar. Biol., 149: 201211. DOI 10.1007/s00227-005-0178-z.

Lin Sun, P.L., Hawkins, W.E., Overstreet, R.M. and Brown 
Peterson, N.J. (2009).Morphological deformities as biomarkers in fish from contaminated rivers in Taiwan. Int. J. Environ. Res. Public Health, 6: 23072331.

Martens, L.G., Witten, P.E., Fivelstad, S., Huysseume, A., Savedreid, B., Vikessa, V. and Obach, A. (2006). Impact of high carbon dioxide on Atlantic salmon smolts (Salmo salar L.): effect on fish performance, vertebral composition and structure. Aquacult, 61(1): 80 -88 .

Nagarajan, M. (2012).Spinal deformities in wild population of Mystus montanus. Int. J. Biological Technology, 3 (3): $23-24$

Nakayama, K., Oshima, Y., Nagafuchi, K., Hano, T., Shimasaki, Y. and Nakayamaj, K. (2005). Early-lifestage toxicity in offspring from exposed parent medaka, Oryzias latipes, to mixtures of tributyltin and polychlorinated biphenyls. Environ. Toxicol. Chem., 24: 591-596.

Naserizadeh, M., Safari, O. and Nematollahi, M. A. (2013). First report on the abnormaility among body component ratios in the caught Caspian Sea Mahisefid (Rutilus frissikutum, Kamensky, 1901). Turk. J. Fish. Aquat. Sci., 13: $383-387$.

Ng, H.H. (2010). Mystus tengara. In: IUCN 2013. IUCN Red List of Threatened Species. Version 2013. 2. <www.iucnredlist.org>. Downloaded on 19 March 2014.

Ng, H.H. and Dodson, J.J. (1999). Morphological and genetic descriptions of a new species of catfish, Hemibagrus chrysops, from Sarawak, east Malaysia, with an assessment of phylogenetic relationships (Teleostei: Bagridae). Raff. Bull. Zool., 47: 45 - 57.

Roberts, T.R. (1992). Revision of the striped catfishes of Thailand misidentified as Mystus vittatus, with descriptions of two new species (Pisces: Bagridae). Ichthyol. Explor.Freshw., 3: 77 - 88.

Saha, H. and Saha, R.K. (2013).Occurrence of innate morphological deformities in fishes of Tripura, North East India - A possible case of Inbreeding. World $J$. Fish \& Marine Sci., 5 (4): 405 - 408. DOI: 10.5829/ idosi.wjfms.2013.05.04.7392

Sarkar, H.L. and Kapoor, B.G. (1956).Deformities in some Indian catfishes.J. Zool. Soc. India, 8: 157 - 164.

Subba, B.R. (1999). Multiple abnormalities in African catfish. J. Inst. Agric. Anim. Sci., 19 - 20: 187 - 191.

Subba, B.R. (2008). Abnormality in Bagarius bagarius (Ham.)(Cypriniformes: Sisoridae) from Nepal. Our Nature, 6: $26-29$.

Tave, D. and Handwerker, T. (1998). Anophthalmia: A non-heritable eye deformity in Oreochromis mossambicus. Ribarstvo, 56 (4): 125 - 130.

Tave, D., Jo, Jae-Yoon.and Kim, D.S. (2011). Gross abnormalities in Tilapia.Fish Aquat. Sci., 14 (2): 148 160. DOI 10.1007/s00227-005-0178-z

Teji, K.T. and John Thomas, K. (2006). Observations on the morphological abnormalities in induced bred larvae of some freshwater fishes. Indian J. Fish.,53 (3): 353 358.

Turner, J.L. and Farley, T.C. (1971). Effects of temperature, salinity and dissolved oxygen on the survival of striped bass eggs and larvae.Calif. Fish Game, 57: 268 - 273.

Weis, J.S. and Weis, P. (1976). Optical malformations induced by insecticides in embryos of the Atlantic silverside Menidia menidia. Fish. Bull., 74 (1): 208 - 211.

Weis, J.S. and Weis, P. (1989).Effects of environmental pollutants on early fish development. Aquat. Sci., 1: 4573. 